\title{
Already in America: Transnational Homemaking AMONg Liberian RefUgeEs
}

\author{
Micah M. Trapp
}

\begin{abstract}
This article explores how refugees at the Buduburam Liberian refugee settlement in Ghana constructed and imagined home in and through a place they have never been to-"America." Drawing on ethnographic examples of homemaking at Buduburam, this article develops the concept of entanglement to show how preferences for and access to the three durable solutions of the United Nations High Commission for Refugees were influenced by centuries of transnational homemaking embedded in the histories of the transatlantic slave trade and colonization of Liberia. Refugees preferred and practised resettlement not as a final destination, but as an active form of transnationalism. The reconfiguration of homemaking through the lens of entanglement demonstrates the importance of developing migratory policies and practices that are attentive to historic and future forms of inequality.
\end{abstract}

\section{Résumé}

Cet article s'engage à explorer la conceptualisation d'un domicile dans l'imaginaire des réfugiés libériens internés au camp de Buduburam, situé au Ghana, pour lesquels l'idée d'un domicile se formait par l'intermédiaire d'un lieu qu'ils n'avaient jamais visité, notamment l'«Amérique». Se basant sur des exemples ethnographiques d'établissement de domicile à Buduburam, l'article, déploie le concept d'enchevêtrement pour démontrer comment les préférences et l'accès relatifs aux trois solutions durables du Haut Commissariat des Nations Unies pour les réfugiés étaient influencés par la nature transnationale d'établir un domicile tout au long des siècles de l'histoire de la traite transatlantique des esclaves et de la colonisation de la Libérie. En ce qui concernait leurs préférences et leurs pratiques, les réfugiés ne considéraient pas la réinstallation comme une destination finale, mais plutôt comme un processus toujours en cours de transnationalisme. Cette reconfiguration de l'idée de réinstallation démontre jusqu'à quel point il est important de développer des politiques et des pratiques reliées à la migration qui prennent en compte les formes d'inégalité historiques ainsi que celles qui pourraient se manifester dans l'avenir.

\section{Introduction}

$\mathrm{F}$ ollowing the outbreak of civil war in 1989, Liberians migrated throughout West Africa. When thousands of Liberians arrived in Ghana in the summer of 1990, the Ghanaian government allocated a piece of abandoned church land in the Gomoa-Buduburam region to be used as a temporary haven for Liberians. About 35 kilometres west of Accra, United Nations High Commission for Refugees (UNHCR) trailers, a camp manager's office, and police station officially marked the entrance of the Buduburam camp, while informal and formal commercial activities of transport and trade offered a less official but vibrant welcome. Over time, Buduburam expanded into a large settlement that intermingled with nearby Ghanaian towns; official population estimates had reached nearly 40,000 in $2005 .{ }^{1} \mathrm{At}$ the time of my research from December 2008 to June 2009, the Buduburam camp was characterized as a protracted refugee situation..$^{2}$ Although refugee camps are framed as a temporary stop on the path to one of the UNHCR's durable solutions (voluntary repatriation, local integration, and third country resettlement), refugees often end up living in camps for a decade or more and in doing so, must confront the paradox of settled life and homemaking in a temporary space. At Buduburam, this paradox was intensified: 
one month into my field research, the UNHCR announced that the camp would be closing in three months, causing immense insecurity among refugees. Though the UNHCR did not implement a cessation clause until June 2012, the prospect of losing refugee status loomed large during my research, and many Liberians anxiously anticipated the loss of their homes and where they would end up within the transnational landscape of durable solutions.

Transnationalism - the social and economic connections across nation-states-is certainly not a new phenomenon in West Africa and has been activated in contemporary refugee settings. For example, Guinean refugees used trans-local networks-"embedded members of family networks that have spanned borders for generations"-to sustain livelihoods in exile. ${ }^{3}$ Refugee experiences were "not so much of a radical interruption of social life, but rather an introduction to a new structure of opportunity and constraint into a much broader social, political, and economic landscape."4 With the establishment of Buduburam, the UNHCR-led migration complex introduced new opportunities and constraints on transnational homemaking. While Liberian refugees practised trans-localism, many viewed resettlement to a third country as the most preferable option. In discussing the reasons and context for this preference, this article suggests that the deep history of transatlantic migrations, which have shaped Liberian society for more than a century, continue to frame contemporary notions of home. In doing so, how does this transnational history interact with the logic and practice of the UNHCR durable solutions?5 By developing a concept of entanglement, I argue that Liberian refugees reconfigured and practised resettlement not as a final destination, but as an active form of transnational homemaking. By rejecting resettlement as an endpoint within one nationstate, Liberian refugees constructed homes and engaged resettlement as an ongoing process within a much larger history. In analyzing how refugees imagined and constructed homes, I demonstrate the historic complexity and ambiguity of resettlement as a "solution." I suggest that contemporary migration policies and the assessment of the need for protection must extend beyond the contemporary conditions and consider the enduring impact of transnational histories of social, economic, and political violence.

\section{The Entanglement of Refugees and Home}

Within the field of transnational studies, home has been conceptualized as existing everywhere and as made through movement, though critics have suggested transnationalism remains an inherently cosmopolitan experience of the privileged few, who have the money and resources to move. ${ }^{6}$ Refugees not only struggle with the affective and material components of homemaking, but also must do so within the requirements and realities of the UNHCR's political framework of durable solutions (voluntary repatriation, local integration, and third country resettlement). The UNHCR model of care remains premised upon individual political protection and requires that refugees prove the need for physical protection as separate from economic and social vulnerabilities. However, scholars have explored notions of home and belonging to demonstrate the fallacy of separating the political, social, and economic needs of refugees. Furthermore, processes of homemaking shaped preference and access to durable solutions.

Stefansson adopted a "pragmatic perception of home" to show how "creating sustainable livelihoods, finding a place of relational identification, [and] developing a site of cultural attachment" all contribute to homemaking, but gave some primacy to the economic condition.7 Pragmatic homemaking among Bosnian refugees meant that the possibilities of a livelihood in exile were compared to livelihoods "at home" before the war. For many, this meant that voluntary repatriation was the preferred durable solution. Hammond conceptualized the migratory experiences of Tigrayan refugees as ongoing processes of emplacement whereby refugees actively cultivated new social networks, livelihoods, and opportunities to create home while in exile. These processes of displacement and emplacement followed Tigrayan refugees in the Sudan "home" to Ethiopia through a UNHCR repatriation process whereby refugees were "returned" to a different part of Ethiopia, where they lacked networks and resources. In this regard, repatriation was not the "best" or natural solution, but a continued cycle of displacement and emplacement. ${ }^{8}$

In third country resettlement, the "solution" is embedded in the redistribution of access to cosmopolitan global resources via a pathway to the global North. Van Hear's distinction between the near and far diaspora suggests that refugees traveling to the far diaspora in the global North access greater economic resources than those who remain in the regional, near diaspora. ${ }^{9}$ Across time and space, the practice of resettlement accumulates real economic potential that is often expressed through imaginative and affective processes. For example, Horst showed how long-term Somali refugees in Kenya experienced the affliction of buufis, extreme desire for resettlement, and eschewed voluntary repatriation (and local integration) in the face of resettlement. Scholars have described such attachment to resettlement as "hoping," "waiting," and "dreaming," thereby relegating the possibility to the imagination. ${ }^{10}$ Such assessments emerge from the reality that less than 1 per cent of the world refugee population will gain access to resettlement and subsequent labelling of resettlement as fiscally inefficient. ${ }^{11}$

However, many Liberians preferred resettlement, particularly to the United States, as the most durable of the 
UNHCR solutions. Scholars have explained the migratory preferences of Liberians in a variety of ways. Tanle applied Kunz's typology of refugee identities (majority, event-related, and self-alienated) to suggest that the conditions of initial flight affected how refugees envisioned the future, where only majority-identified refugees were likely to prefer a return home to Liberia. ${ }^{12}$ Byrne suggested that three forms of national identity (ethnocultural, civic, and liberal) shaped preferences: refugees who embraced a liberal nationalism based on the visions of the freed slaves who settled Monrovia in the early nineteenth century were more likely to prefer resettlement. ${ }^{13}$ Others have pointed to the importance of history and primacy of economic concerns in shaping contemporary migration. Omata confirmed the fallacy of homecoming by articulating the trouble of finding a job in Monrovia and the necessity of AmericoLiberian social connections. ${ }^{14}$ Tete explained the ongoing interest in resettlement among Liberians as a "dual idea of home," whereby refugees articulated a desire for resettlement as a means to gain "the necessary education, skills and economic empowerment to be able to contribute now in absentia, but also enable them to return [to Liberia]." Resettlement would allow them to "go home with something." ${ }^{16}$ This body of literature suggests an incompatibility between Liberian notions of transnational homemaking as a process and the UNHCR approach to durable solutions as a final destination.

Aiming to improve the durable solution of resettlement, the UNHCR Working Group on Resettlement proposed a "strategic use of resettlement" that would provide benefits beyond individual refugees. ${ }^{17}$ To achieve this goal, the working group identified the need to increase global capacity for resettlement and, notably, the elimination of economic pull factors for resettlement. ${ }^{18}$ Furthermore, resettlement states would need to relinquish domestic political agendas, at least to some extent, to focus on collective state decision-making for refugee migrations. ${ }^{19}$ While admirable, state collective decision-making potentially overshadows the specific political and economic histories (and subsequent state responsibilities) that may have contributed to displacement in the first case.

Through a case study of transnational homemaking among Liberian refugees, I develop the concept of entanglement to demonstrate how political histories connect to the practice of the UNHCR durable solutions. In physics, quantum entanglement-what Einstein referred to as "spooky action at a distance"-marks an intense, yet potentially precarious relationship that occurs when two particles previously in contact with one another, maintain a direct relationship over time, despite being separated by vast distances. ${ }^{20}$ While scientists do not know why quantum entanglement exists, it offers a provocative metaphor for exploring transnational homemaking practices among Liberian refugees. Objects in quantum entanglement exist in direct correlation to one another; "when you measure one half of the entangled pair, the other half instantly assumes the exact opposite state" without physical contact or other communicative means. ${ }^{21}$ In this article, I use entanglement to mark the habitual ways in which the migratory histories of transatlantic slave trade between West Africa and North America and the U.S. colonization of Liberia influence and mediate contemporary practices of transnational homemaking. ${ }^{22}$ In particular, an analysis of entanglement brings attention to how the histories of exploitation and colonization often invisibly affect and frame both contemporary practices of transnational homemaking and migration policies.

\section{Research Methods}

During my first anthropological research trip to Buduburam from May to July 2005, I lived with a family in a central and densely populated part of the settlement. My host was a Liberian woman in her 30 s who had lived in the house for six years and was, at the time, providing a home for a young girl who was in process for resettlement to the United States. The three of us shared a rather comfortable space, including a living room, kitchen, two bedrooms, and indoor stall for showering. The year of 2005 was a vibrant time for the camp: many refugees were able to travel to the United States via a resettlement program. During my second research trip from December 2008 to July 2009, I rented a house on the outskirts of the camp through referral of my previous host. The house was relatively luxurious, given its porch, higher ceilings, and most importantly, its indoor commode (though there was no running water). My neighbours were both Liberian refugees and Ghanaians, and my participantobservation within the neighbourhood and various forms of domestic life-cleaning, washing outside, hauling water, cooking, and sharing food-provided me with privileged access to camp life and serves as the foundation for this article.

Three research assistants, all of whom were Liberian community health workers, facilitated and supported my research. We conducted semi-structured interviews with 28 Liberian households, three focus groups, and a household survey in 132 Liberian households. ${ }^{23}$ Semi-structured interviews collected data on household conditions, economic strategies, and migratory options. Participants were intentionally selected, with the help of my research assistants, to represent a socio-economically diverse group. Interviews lasted one to two hours, were conducted in a mixture of Liberian English and English, depending on the preference 
of the interviewee, and were recorded and transcribed. Additional informal follow-up interview sessions took place when necessary. Focus groups comprised five to six participants who were selected to represent different population sectors based on gender, age, and education. Each session followed a prepared list of questions regarding social status and migration and lasted approximately two hours. The household survey was administered to a randomly selected sample of 119 households and 23 of the 28 households that participated in a semi-structured interview. ${ }^{24}$ The 119 households were selected using a random number generator to identify zone (neighbourhood) and household numbers. All survey participants completed a social resource map to illustrate geographic (Liberia, Buduburam, West Africa, "overseas") flows of monetary, food, household provisions, labour, and social resources. Participants allocated 200 beans among the different resources to measure relative importance.

Additionally, I conducted eleven stakeholder interviews with UNHCR, camp management, resettlement staff, and non-profit organizations. To provide some, albeit limited transnational context, I travelled to Liberia for two weeks in May 2009. I conducted one in-depth interview with a former refugee from Buduburam with whom I had conducted interviews in 2005. I also conducted five interviews with Liberians who had not lived at Buduburam. Participants were selected using snowball methods and interviews were conducted in Liberian English. Interviews lasted between thirty minutes and two hours and focused on homemaking and reception of returning Liberians.

\section{A History of Entanglement in Liberia}

While many refugee populations have expressed significant interest in resettlement to the United States (among other destinations) as the solution to long-term refugee camp life, preference for and attachment to America remains historically particular and unique for Liberians. Liberian ideas and practices of citizenship and home have long since been negotiated in a transnational context linked directly to the United States. ${ }^{25}$ In the early 19th century, the American Colonization Society (ACS) formed "to promote and execute a plan for colonizing (with their consent) the free people of color, residing in our country, in Africa." ${ }^{26}$ Prompted largely by the desire to rid the United States of freed black men, the ACS recruited small numbers of settlers, who were primarily middle-class, free black men, whose success in the United States was limited by pervasive racism. ${ }^{27}$ Politicians, social notables, and scholars have used various terms to describe the subsequent relations that emerged between the U.S. and Liberia, including ' 'maternal relations,' ... 'object of peculiar interest,' 'an imperative duty,' 'the nation's ward,' 'at no time a colony of this government,' 'our national duty,' 'a moral obligation,' 'peculiar relations.'”28

Within Liberia, the new Constitution aimed to prevent discrimination similar to that experienced in the United States by restricting citizenship to blacks. However, political power became consolidated in the True Whig Party of the Americo-Liberian settler elite, and indigenous Africans were denied rights to citizenship and land. ${ }^{29}$ A non-Americo-Liberian could petition to individually own land, but would have to be Christian and adopt a Western lifestyle in order to be considered for citizenship. ${ }^{30}$ Such assimilative demands to become "civilized" were further enhanced by education and occupation and became embodied through Western-style dress and home, eating habits, driving in cars, and the furnishing and care of the home. Elite Liberians sent their children to the United States for education before returning to Liberia to inherit prominent government positions, thereby socially reproducing the position and power of the True Whig political monopoly.

However, the power of the True Whig Party must be couched within a deeper history of transnational exploitation. During an interview with Patience, a Liberian humanitarian aid worker in Ghana and self-identified Americo-Liberian, she explained that she was from the state of Georgia but lived and worked in Ghana and also travelled back and forth to Liberia. While her transnationalism required vast resources to maintain and differed from the realities of refugees who did not have ready access to America, Patience explained that Africans had sold her ancestors to American slave traders: "So who was colonized?" she challenged. In posing this question, Patience's account framed the transatlantic slave trade as an exploitative precursor to the construction of the Americo-Liberian settler elite. In the following sections, I explore how these competing and interconnected transnational entanglements informed how refugees approached and made homes within the durable solutions framework.

\section{Wasted Years and Remote Renters: Liberia Cannot Yet Be Home}

With an end objective of closing the Buduburam camp, the UNHCR and Ghanaian government worked to actively promote voluntary repatriation. In 2009, this included the creation and screening of a video in which refugee returnees in Liberia testified to ample livelihood opportunities. Refugees at Buduburam responded with disgust and irritation that the UN and Ghanaian government would try to tell them about life in their homeland. This section outlines refugees' own perceptions of home and demonstrates how the durable solution of voluntary repatriation was evaluated through a transnational history of entanglement such that 
a direct return home to Liberia was not possible for many refugees.

\section{Wasted Years}

Few refugees felt they had a clear path home to Liberia: only 27 households (20 per cent of the 132 surveyed) at Buduburam owned a house or land in Liberia, though a few were saving for a house and many dreamed of building a house in Liberia. For those without a home or land in Liberia, the prospect of return was especially risky and was further challenged by transnational notions of social status, as I demonstrate through the example of Blessing. Blessing arrived at Buduburam in 1992 without her family, but had since given birth to three children. Blessing was able to find only odd jobs-washing clothes or braiding hair-in nearby Ghanaian towns. Her income was unstable, and she often relied heavily on the goodwill of others and non-profit organizations to help her out. When I first met Blessing, she and her children lived in one bedroom of a two-bedroom house; the single room, lit by a dim blue light bulb, contrasted starkly with her childhood in Liberia.

My father had a car. We attended Catholic school. The Catholic schools in Liberia are very expensive. Your father will pay for everything in the school, books, study class, everything. And they carry you to school, the driver carry you to school. Even in Liberia, some of us, our mothers not used to cook because they have to go to work. They have somebody in the house to cook and wash our clothes ... So that how it looked like. You say this person have money because their house have air condition, you have fresh toilet, you have inside kitchen. You don't use that pot outside. Everything in the house.

Blessing's recollection of her past reflects the lifestyle attached with being "civilized," yet she did not believe a similarly prosperous future would be available to her in Liberia. Since she lost her parents and family in the war, "if I enter Liberia, I will be a stranger. [People] will look down upon me [and ask] 'What thing she come to do here?' I don't have anything. Nobody will even have much time for me. At least staying here, I don't have to start over." Blessing's concern about the circumstances under which she could return to Liberia reflected broader fears of being labelled as "wasted years." "Wasted years" was a derogatory term used in Liberia to describe people who had lived at the camp for a long time and then returned to Liberia with nothing. During my visit to Liberia, I spoke with a young woman in her 30 s about the stigma of "wasted years." Victoria used to live at Buduburam and had since returned to Liberia, but typically did not tell people that she had lived there. Victoria's concerns about being stigmatized were echoed in my conversation with a student at the University of Liberia. While the student had never been to Buduburam, she described the camp as a bad place, where people were just wasting time and living the high life, drinking alcohol at the expense of their family members who supported them. Facing such negative prospects of reception, refugees at Buduburam were intent on avoiding the label of "wasted years."

Historically, access to the uppermost margins of being "civilized" was highly structured, but the system maintained flexibility: a person could be considered a "civilized country" man, such that kui (civilized) was epitomized by settler life, but was not restricted to it. ${ }^{31}$ In this system, "native" children could potentially gain access to "civilized" status through the foster system, whereby "civilized" kin and non-kin had "native" children within the house to perform household chores in exchange for "civilized" training and possibly education..$^{32}$ In the context of exile, acquiring education while outside of Liberia was the primary way that refugees could return to Liberia with social status intact or improved. ${ }^{33}$ However, schools at Buduburam were generally dismissed as poor-quality "refugee schools" (classes were often cancelled when teachers had migratory paperwork to take care of), though some educational opportunities in Ghana proved beneficial for return. For example, Johnny felt confident he would be respected upon return to Liberia, because he had received a scholarship to attend university in Ghana. Such opportunities were scarce, and third country resettlement became a key means of potentially obtaining "civilized" status.

Samuel believed that earning a degree from a university in the United States would shift his identity from "wasted years" to a successful man educated in America. Although Samuel had gained employable skills through computer training and his work experience with NGOs at Buduburam, his younger cousin had earned a BA in Liberia, leaving Samuel uncertain about his status, should he return. As an example of transnational entanglement, the meaning and status of an American BA reflects a transnational entanglement: the Liberian university degree would automatically shift and decrease in relation to an American degree.

If educational opportunities were not available, the fiscal resources associated with the far diaspora of America offered an alternative route to increased status. Helena, a young mother of six, who was not formally educated, explained that many people wanted to go to America get a job-any job - where they would work hard and save money that they would eventually use to build a home in Liberia. Helena explained that saving \$15,000-\$20,000 in America would be enough to build a house in Liberia. Helena even claimed she could have a "book-learned" (educated) person minding the house for her. Refugees at Buduburam 
thus situated resettlement as an opportunity for or means by which an eventual physical and social return to Liberia would be made possible. This transnational route to upward social mobility via the far diaspora situated Buduburam as a new space through which Liberians might interject themselves-through resettlement to America-into the "civilized" social and political terrain of status and prosperity in Liberia.

Despite these aspirations, at the time of my research, U.S. resettlement programming for Liberians had shifted primarily to the Prioity-3 resettlement program. P-3 programming required a family member already in the United States to sponsor the resettlement of incoming refugees. Thus, refugees were able to travel to the U.S. only if they had a family member willing to sponsor them. This system reflected the basic patronage structure of becoming "civilized" via a foster system, such that through resettlement, refugees could potentially access education and fiscal resources. ${ }^{34}$ The $\mathrm{P}-3$ program placed the onus and responsibility for transnational opportunities on personal relationships and swayed access to the system in favour of those with existing transnational resources. For example, Blessing-a UNHCR-verified refugee-wanted to resettle to America to work, send her children to school, and save money to buy a house in Liberia, but she did not have family to sponsor her.

\section{Remote Renters}

From the perspective of many refugees, resettlement would not only potentially relieve the economic burdens of refugee camp life and provide transnational opportunities to improve one's education and social status, but it was also a way to contribute to the development and improvement of Liberia. In the postwar period, the Liberian nation has turned to its people in the diaspora to invest in the rebuilding of the war-torn country. When elected in 2006, president Ellen Johnson-Sirleaf subsequently appointed fellow Liberians from the U.S. diaspora to key Cabinet positions in the Ministries of Commerce, Finance, Information, Labour, and Agriculture. 35 In some ways, these appointments reinforced the continuing importance of transnational entanglement in shaping Liberian social and political structures and raised concern about the replication of history: "Could the[se] returnees constitute a political enclave ... based on their orientation as people who lived abroad during the war, acquired certain skills, and now have the capital and expertise with which to contribute to the country's political development?"36

Nonetheless, from the auditorium stage at the University of Liberia in 2009, President Johnson-Sirleaf addressed the members of the Liberian Studies Association, many of whom were Liberians living in the United States, and called for a return of the far diaspora: "Liberia is indeed back and open for business ... Explore the possibilities of coming home. Go beyond just checking it out, to actually feeling it ... and come home." ${ }^{37}$ However, when the presence of Liberians in Ghana had come to a confrontation just a year before, a chief spokesman for the Liberian government, Dr. Laurence Bropleh stated, "The government is not in the position to receive 30,000 or even 10,000 or 5,000 [refugees] tomorrow ... please put a stay order on sending an exodus of Liberians to Liberia right now..$^{8}$ Refugees from Ghana were considered an economic burden and liability compared to the development potential that was attributed to their fellow Liberians in the far diaspora. Despite the development promises of the far diaspora, the prevalence of such remote renters influenced the homemaking potential of other Liberians and refugee returnees.

On a May evening in Monrovia, I enjoyed a sunset view over the water while sitting on the balcony of a government official's home. He had lived in the United States for years, but had taken a position in the Liberian government once President Johnson-Sirleaf had been elected. His family continued to live in the United States while he commuted to Monrovia. His rented apartment was nicely furnished with a large television and sound system along with a refrigerator well-stocked with cold beverages. During my brief visit to Liberia, I had heard complaints about such remote renters, who worked for the government and commuted between the United States and Monrovia, occupying much-needed housing resources as a result of their ability to pay comparatively large sums of money in rent. As one man explained, "People go out from Liberia and stay out-they do not come back home and invest. You have plenty of people with high positions in Liberia, but do not own a home there."39 Refugees wanted to obtain a voice and stake a claim in the future of Liberia. They wanted to go beyond the contributions of Liberians in the far diaspora, who they believed did not maintain an interest in Liberia as a nation. The following section further explores how transnational entanglements shaped unequal access to resettlement and homemaking in Liberia.

\section{Bank of America, Refugee Mansion, Real Mansion: Inequality and Entangled Solutions}

In 2008 and 2009, the economy of the camp reflected the general downturn in the global economy. People pinched resources, often described their condition as "just managing," and were uncertain about what the future held. Many refugees had built homes and lives at the camp, and the cessation clause threatened their way of being. In light of these looming anxieties, refugees struggled to evaluate and gain access to their preferred durable solution. This 
section examines the intersections between homemaking and the durable solutions to demonstrate how transnational entanglements created unequal access to resettlement.

\section{Bank of America}

Of the 132 households surveyed, 28 (21 per cent) had an adult employed, primarily in non-profit organizations and schools, though in many cases the salaries were small, often paid late, or did not materialize at all. The majority of households (93 or 71 per cent) relied on small business income, ranging from selling small bags of seasoning, oranges, or water to more lucrative cookshops and clubs. Underneath this backdrop of livelihood strategies at Buduburam, financial remittances played a crucial role in the camp economy, homemaking, and preferences among the durable solutions.

According to my survey data, twenty-six households (20 per cent) received regular monthly remittances; twentyfour households (18 per cent) reported remittances every few months; twenty-three households (17 per cent) received irregular remittances; seventeen (13 per cent) had received one remittance; and forty-two households (32 per cent) did not receive remittances. While aggregate remittance amounts at Buduburam dropped by nearly half from 2007 to 2009 and constituted an unstable livelihood, the material and transnational significance of remittances continued to influence Liberian notions of home and access to durable solutions. ${ }^{40}$ While remittances could funnel muchneeded assistance directly into the hands of refugees, they were also capable of exacerbating and fostering local and transnational inequalities. ${ }^{41}$ For example, at Buduburam, Mary-a young mother of two-had been receiving regular monthly remittances from her younger sister, who had resettled in the United States thirteen years ago. Mary joked that her younger sister had become her "ma" and was now "bigger" than she because she was supporting the family. Such inequalities manifested in homemaking practices at Buduburam and shaped perceptions of resettlement.

Anyone at the camp who demonstrated wealth or a comfortable lifestyle was often labelled as "already in America." Tita and Lucy both described each other's homes at Buduburam as "already in America." Tita's home included a small, furnished kitchen with a dish-draining rack, refrigerator, table, stool, and fan. Her bedroom had another fan, a television, and a computer. Lucy was "already in America" because of her lifestyle habits-drinking juice or lemonade, eating pancakes-and the travel opportunities that had become available to those who had lived in her home. Of the twenty-five people that had stayed or lived with Lucy over the last decade, ten had been resettled to the United States, some of whom occasionally sent financial remittances to Lucy, which led many people to refer to her as the "bank of
America." The use of a bank to describe Lucy's home did not merely symbolize wealth, but also pointed to the importance of access to and the ability to draw upon and distribute transnational resources. While the UNHCR provided protection and solutions on the basis of political need, the everyday realities of refugee camp life and its surrounding transnational family lives were mired in the economic inequalities (and opportunities) embedded in the durable solution of resettlement.

The idea of America and opportunities associated with resettlement reflected the historic entanglement between Liberia and the United States via the homemaking practices of those who returned for a visit to Buduburam following resettlement. For example, when Elena's brother came to Buduburam from America, he did not stay in her home, but in the hotel at the camp. As Elena explained, the conditions in her home were not conducive to his needs: the hotel offered electricity backed by a generator, air conditioning, running water, and a private shower and bathroom. To ensure her brother's comfort, Elena felt compelled to cater to the higher taste standards that she assumed her brother had developed since living in America. She went to the market as early as possible in the morning to buy the best fish for him since "zipper" fish (a small Ghanaian fish produced for local consumption rather than export) would not satisfy his tastes. Beyond confirming the worthiness of pursuing resettlement for those who remained in Ghana, the visibility of such returnees, many of whom were on their way to Liberia to build a home, further shaped resettlement as a route home.

Similar to the prospect of wasted years upon return to Liberia, homemaking at Buduburam was evaluated through the relative anticipation of the durable solutions. For example, homes that were "already in America" or like a "bank of America" remained distinct from houses at Buduburam that were furnished with the remains of transnational travel. Robertson had purchased his one-bedroom home at Buduburam from a friend who had travelled on a resettlement program. On the surface, Robertson's home was nicely furnished, yet his narration of the space revealed a different reality. The kitchen was furnished with a twoburner cookstove, but the gas tank was empty and Robertson had not used it for two months, nor did he have money to fill it. The kitchen table was bare, except for a stray ice cube tray, but Robertson did not have a refrigerator or freezer. The sitting room had a small wooden table flanked by a chair and love seat, both of which had wooden frames and were covered with foam cushions. Robertson was careful to explain that his home furnishings were not a reflection of his wealth, because he had inherited them from people who had travelled. At second glance, the dissonance-the shelf of VHS 
tapes and visible lack of a television or VCR-became even clearer. The ability of his friend to leave behind these material goods, things that anyone repatriating to Liberia would have taken with them, reflected and reproduced the promise of prosperity through resettlement. At the same time, the ultimate dysfunction of these goods reflected the increasingly hallowed presence of resettlement for those who remained at Buduburam as well as the inability of the place of Buduburam to activate the lifestyle of America.

\section{Refugee and Real Mansions}

In seeking political asylum, refugees were considered guests in Ghana, though they could potentially gain longterm access and rights to live in Ghana as members of the Economic Community of West Africa States (ECOWAS). However, many Liberians did not perceive local integration at Buduburam or elsewhere in Ghana as a durable solution. Rather, life in Ghana was evaluated in relation to transnational resources and the homemaking prospects available through repatriation and resettlement, as I demonstrate through the homemaking practices and migratory preferences of Mercy and Lillian.

Mercy lived in a sunny orange house that was flanked on two sides by a garden and small patio. A large tree with a painted trunk near the patio provided shade over the area that served as a sitting and cooking area. A wooden doorframe was covered with a chicken-wired screen to allow breezes to pass into the house. The door opened into an indoor cooking area with a one-burner kerosene stove and small refrigerator. Beyond the kitchen were two bedrooms, both with televisions, and a fan. As one of "the originals," Mercy came to Buduburam in 1990, when the camp was just a collection of tents and a few concrete housing structures owned by the Ghanaian government. Mercy had built her house by selling portions of her rice rations to buy concrete blocks and was able to get a piece of tin that had been distributed by the UNHCR for roofing.

Prior to the war, Mercy married a Ghanaian man in Liberia. Since fleeing to Ghana together, Mercy's husband had obtained a job in Accra that provided a small income for the family. Porter et al. have argued that the cultivation of bridging or linking capital with Ghanaians provided greater opportunities for sustainable livelihoods than those who focused only on bonding capital with fellow Liberians. ${ }^{42}$ In Mercy's case, her husband's job allowed her to furnish her home and provide access to educational opportunities for their sons; however, the money he earned was barely sufficient to sustain the family, and Mercy expressed great insecurity. Her two daughters had been resettled to the United States and England, but they contributed little to Mercy's livelihood. Adding further uncertainty to her future, Mercy believed she was the owner of her home (she had built it after all), but also knew that her home was on land owned by the Ghanaian government, and a representative from the Ghana Refugee Board confirmed that refugees would eventually be asked to vacate the houses and land at Buduburam. ${ }^{43}$ Given these constraints, Mercy maintained resettlement as part of the solution for a long-term livelihood plan. While she believed she was too old to travel to America and earn money, she wanted one of her sons to resettle so that he would be able to earn money and support her through remittances.

Lillian also faced limits to homemaking through local integration, but did not have a vision of resettling to America. When I first met Lillian on a Sunday afternoon, she was dressed in a full African suit and carried a matching purse. The heeled sandals she wore made her seem even taller inside the low-ceilinged house where we chatted. While her host teased her for dressing "big" and "bluffing" (showing off), Lillian did not hide her lifestyle and what she hoped to achieve. With financial help from her sister who lived in the United States, Lillian had leased a plot of land at the camp from a Ghanaian man and had built a large house. After our first meeting, Lillian offered to give me a tour of her "refugee mansion," as she called it. A front porch welcomed us into a large living room with high, airy ceilings. The painted walls were sparsely decorated with several formal photographs of Lillian and her family, along with several plastic flower arrangements. A television and stereo were pushed against the walls and complemented the spaciously arranged furniture. A hallway led to three bedrooms, while the indoor kitchen at the far end of the house led to a second entrance/exit and porch. Lillian insisted that this was only her "refugee mansion" and that she would build her "real" mansion in Liberia.

Even though Lillian had built a home on private land, she faced risks similar to Mercy's. Shortly before she gave me this tour, Lillian's landlord had returned to Buduburam, because her land lease had expired, and he demanded that she start paying rent to live in her own home. While Lillian faced limits to the sustainability of local integration, her access to transnational resources afforded her some flexibility within the durable solutions. Lillian's family was spread through West Africa and the United States, and her decision to live at Buduburam (and subsequent fiscal reliance on remittances) had not hampered her social status within her extended, transnational family. She was still considered and consulted on important family decisions, despite her inability to fiscally contribute to the transnational household. Rather, her transnational social networks and continued access to America resulted in a degree of mobility that was unparalleled by the experiences of most refugees, who faced 
significant limitations upon return to Liberia. In this regard, Lillian's return to Liberia did not require access to resettlement, but was nonetheless rooted in the long-standing entanglements of homemaking in America and Liberia.

\section{Resettlement as Slavery: Entanglement and the Limits of Resettlement}

While those eschewing resettlement often had such access to transnational resources, others retained a critical perspective on the entanglement between the United States and Liberia, regardless of their individual prospects for homemaking. One afternoon in June, Solo, a young man who had few prospects for homemaking in Liberia or the United States, shared a book about Liberian history. I lay with my back against the cool tiles of the floor, trying to catch a breeze through the chicken-wired door as I read excerpts out loud and asked questions to my hosts. Our conversation meandered through Liberian history, eventually coming to a discussion about the contemporary practice of resettlement.

"Resettlement is modern slavery," proclaimed Solo. I bolted up, eager to hear some critical insight into the favoured travel route. "It's like slavery," Solo explained, "because they [the UNHCR and the U.S. government] took [sic] people from the camp ... and all you do is work in some low-paying job." Solo elaborated by recounting the story of a well-known lawyer who had been resettled to America, where he worked in a restaurant washing dishes while his supervisor was a young girl without college education. Similarly, a man who used to be the commissioner of his town in Liberia began working in a grocery store in America. Both experienced significant losses in social status and pride, which were, in Solo's estimation, not unlike the massive decrease in status, pride, and dignity experienced during the transatlantic slave trade. Solo's critique of the realities of resettlement reflects an expanding literature documenting the individual experiences and challenges of resettlement and integration. ${ }^{44}$ However, Solo also pointed to the broader transnational impact of resettlement. By equating resettlement with the exploitative system of slavery, his critique highlighted the potential for resettlement to (re)produce the systemic inequalities of centuries of transnational entanglements of homemaking and pointed to the limits of this solution.

\section{Conclusion: Enduring Entanglements in Migration Policy}

In this article, I have suggested that an enduring transnational entanglement between the United States and Liberia has shaped contemporary processes of homemaking and the practice and potential of the UNHCR's durable solutions for Liberian refugees in Ghana. The Buduburam camp existed as a liminal space, an intermediary between these two sites of homemaking: as an intersecting point in this history, homes at Buduburam rendered visible the complex dynamics of transnational homemaking and challenged existing dual notions of homemaking. ${ }^{45}$ The ethnographic examples of homemaking-wasted years, remote renters, bank of America, refugee mansions, and real mansions-demonstrated how contemporary resettlement opportunities in the far diaspora intersected with centuries of transnationalism. Homemaking in the temporary space of the Buduburam camp was actively contested, was inherently transnational, and existed in relation to the potential of the UNHCR durable solutions. Through the concept of entanglement, I suggested that homemaking among Liberian refugees existed in dynamic relation to past, present, and future transnational sites of home. In quantum entanglement, "when you measure one half of the entangled pair, the other half instantly assumes the exact opposite state," without physical contact or other communicative means. When refugees created a home at Buduburam, the meaning and practice of home at another site assumed an alternative, if not opposite meaning.

My analysis focused on two sets of entanglement: wasted years and remote renters, as well as bank of America and refugee/real mansions. The socially constructed fear of becoming wasted years was entangled with the power and status of remote renters, who had access to and often lived in the far diaspora. When government employees occupied homes in Monrovia as remote renters, refugees without means at Buduburam, such as Blessing, assumed the opposite state of homemaking: they could not return to and make homes in Liberia. In the example of homes like the "bank of America," "refugee mansions," and "real mansions," the concept of entanglement revealed the complex relationships between far diaspora resources and the need for resettlement. Comfortable homes at Buduburam became physical manifestations of the status and wealth associated with the far diaspora; refugees who inhabited these homes were not in need or search of resettlement as a route home to Liberia. Here, the prospect of resettlement took on the opposite state, as the reality of performing demeaning labour in the United States rendered resettlement useless in the broader pursuit of homemaking in Liberia. Instead, the enduring transnational entanglement between America and Liberia enabled Gloria, for example, to access far diaspora resources to construct her real mansion in Liberia. However, Solo's critical insight about the realities of homemaking through resettlement challenged and disrupted the unspoken entanglements of transnational status-making between the United States and Liberia. By disentangling the complex histories and relationships that inform contemporary meanings and practices of homemaking, the transnational 
processes shift from "spooky action at a distance" to reveal clear connections between place and allow for conscious intervention. ${ }^{46}$ I conclude with some suggestions for how we might start to disentangle the links between homemaking, the durable solutions, and migration policy.

To ensure the sustainability of the durable solutions, contemporary forms of transnational migration, exchange, and assistance must be rendered historically specific. In the context of the UNHCR durable solutions, the entanglements of home suggest that resettlement programs must be conceptualized as automatically connected in relation to other migration policies as well as practices and meanings of home. For example, to fully understand the potential and limitations of resettlement, national resettlement programs need to be recognized as such, even though they may be facilitated through the "neutrality" of the multilateral humanitarian aid system. In the case of Liberians, the question of "where is home?" has inevitably invoked the geographies of West Africa and North America and the political territories of Liberia and the United States for centuries. However, once refugees arrive in the United States, the terms of resettlement policy rarely include consideration of enduring and unspoken historic entanglements, such as those presented in this article. By framing homemaking as a transnational entanglement that continues to enact the connections of place-based inequalities through habituated relationships, more effective migration policies can be developed through the disentanglement of transnational homemaking practices. Moreover, the approach of homemaking as a transnational entanglement shifts the notion of the UNHCR durable solution from a one-time event and static endpoint to complex, ongoing processes of engagement that demand conscious intervention.

Micah M. Trapp is an assistant professor in the Department of Anthropology at the University of Memphis. Her current research focuses on humanitarianism, food aid, and the role of taste in the political lives of refugees. The author may be contacted atmmtrapp@memphis.edu.

\section{Notes}

1 United Nations High Commission for Refugees, "Ghana," UNHCR Statistical Yearbook, 345, http://www.inhcr. org/4641be5011.html.

2 UNHCR, "Protracted Refugee Situations: Millions Caught in Limbo, with No Solutions in Sight," 10 Stories the World Should Hear About, 2006, http://www.un.org/events/tenstories/o6/story.asp?storyID $=2600$. A protracted refugee situation as "one in which refugees find themselves in a long-lasting and intractable state of limbo. Their lives may not be at risk, but their basic rights and essential economic, social and psychological needs remain unfulfilled after years in exile."

3 Lacey Andrews Gale, "Sustaining Relationships across Borders: Gendered Livelihoods and Mobility among Sierra Leonean Refugees," Refugee Survey Quarterly 25, no. 2 (2006): 70.

4 Ibid.

5 For a discussion of transnationalism as a durable solution, see Nicholas Van Hear, "Refugees in Diaspora: From Durable Solutions to Transnational Relations," Refuge: Canada's Journal on Refugees 23, no. 1 (2006): 5-14; Nicholas Van Hear, "From 'Durable Solutions' to 'Transnational Relations': Home and Exile among Refugee Diasporas," Occasional Paper 23 (2014): 232-51.

6 Nigel Rapport and Andrew Dawson, "Home and Movement: A Polemic," in Migrants of Identity: Perceptions of Home in a World of Movement, ed. Nigel Rapport and Andrew Dawson, 19-37 (New York: Berg, 1998); Karen Fog Olwig, "Epilogue: Contested Homes; Home-making and the Making of Anthropology," in Rapport and Dawson, Migrants of Identity, 225-36.

7 Anders H. Stefansson, "Refugee Returns to Sarajevo and Their Challenge to Contemporary Narratives of Mobility, in Coming Home? Refugees, Migrants and Those Who Stayed Behind, ed. Lynellyn D. Long and Ellen Oxfeld (Philadelphia, University of Pennsylvania Press, 2004), 174.

8 Laura C. Hammond, This Place Will Become Home: Refugee Repatriation to Ethiopia (Ithaca, NY: Cornell University Press, 2006); Hammond, "Examining the Discourse of Repatriation: Towards a More Proactive Theory of Return Migration," in The End of the Refugee Cycle?, ed. Khalid Koser and Richard Black, 227-44 (New York: Berghahn Books, 2004); Oliver Bakewell, "Returning Refugees or Migrating Villagers? Voluntary Repatriation Programmes in Africa Reconsidered," Refugee Survey Quarterly 21 (2000): 42.

9 Nicholas Van Hear, New Diasporas: The Mass Exodus, Dispersal and Regrouping of Migrant Communities (Seattle: University of Washington Press, 1998).

10 Cindy Horst, Transnational Nomads: How Somalis Cope with Refugee Life in the Dadaab Camps of Kenya (New York: Berghahn Books, 2006); Karen Jacobsen, The Economic Life of Refugees (Bloomfield, CT: Kumarian, 2005).

11 UNHCR, "Resettlement: A New Beginning in a Third Country," 2011, http://www/unhcr.org/pages/4a16b1676 .html; Jacobsen, Economic Life of Refugees.

12 Augustine Tanle, "Refugees' Reflections on Their Stay in the Buduburam Camp in Ghana," GeoJournal 78, no. 5 (2013): 879 .

13 Jennifer Byrne, "Should I Stay or Should I Go? National Identity and Attitudes towards Local Integration among Liberian Refugees in Ghana," Refugee Survey Quarterly 32, no. 1 (2013): 53, 68 .

14 Naohiko Omata, "Community Resilience or Shared Destitution? Refugees' Internal Assistance in a Deteriorating 
Economic Environment," Community Development Journal 48, no. 2 (2013): 269, 274.

15 Suzanne Y. A. Tete, “'Any place could be home': Embedding Refugees' Voices into Displacement Resolution and State Refugee Policy," GeoForum 43 (2012): 113.

16 Abby Hardgrove, "Liberian Refugee Families in Ghana: The Implications of Family Demands and Capabilities for Return to Liberia," Journal of Refugee Studies 22, no. 4 (2009): 483-501; Alice Boateng, "Survival Voices: Social Capital and the Well-being of Liberian Refugee Women in Ghana," Journal of Immigrant \& Refugee Studies 8 (2010): 386-408.

17 UNHCR, "The Strategic Use of Resettlement by the Working Group on Resettlement," June 2003, http://www.unhcr. org/protect/PROTECTION/3ee6dc6f4.pdf.

18 Ibid., 6.

19 Ibid., 6-9.

20 Laura Sanders, "Everyday Entanglement: Physicists Take Quantum Weirdness out of the Lab," ScienceNews, 5 November 2010, http://www.sciencenews.org/view/ feature/id/6506o/description/Everyday_Entanglement.

21 Sebastian Anthony, "The First Quantum Entanglement of PhotonsthroughSpaceandTime," ExtremeTech,24May2013, http://www.extremetech.com/extreme/156673-the-first -quantum-entanglement-of-photons-through-space-andtime.

22 I use "the United States" to refer to the geo-political space and "America" to refer to the ideational space constructed by Liberians.

23 Additional household interviews (three) and surveys (fourteen) were conducted with Ghanaian households on the camp, but these data are not included in the analysis presented here.

24 Four of these households repatriated to Liberia, and one household head was critically ill and unable to participate.

25 For additional historical context and analysis, see Nnamdi Azikewe, Liberia in World Politics (London: Arthur H. Stockwell, 1934); Yekutiel Gershoni, Black Colonialism: The Americo-Liberian Scramble for the Hinterland (Boulder, CO: Westview, 1985); Lamin Sanneh, Abolitionists Abroad: American Blacks and the Making of Modern West Africa (Cambridge, MA: Harvard University Press, 1999); Amos Sawyer, The Emergence of Autocracy in Liberia: Tragedy and Challenge (San Francisco: Institute for Contemporary Studies, 1992); P. J. Staudenraus, The African Colonization Movement 1816-1865 (New York: Columbia University Press, 1961).

26 American Colonization Society, The First Annual Report of the American Society for Colonizing the Free People of Color of the United States: and the Proceedings of the Society at their Annual Meeting in the City of Washington, on the First Day of January, 1818 (Washington City, 1818).

27 Mary H. Moran, Civilized Women: Gender and Prestige in Southeastern Liberia (Ithaca, NY: Cornell University Press, 1990), 58.
28 Azikewe, Liberia in World Politics, 18.

29 Gershoni, Black Colonialism, 104. Africans did not obtain the right to vote until 1946.

30 Ibid., 37-8.

31 Elisabeth Tonkin, "Model and Ideology: Dimensions of Being Civilised in Liberia," in The Structure of Folk Models, ed. L. Holy (New York: Academic, 1981), 319.

32 Moran, Civilized Women.

33 Hardgrove, "Liberian Refugee Families."

34 Gale, "Sustaining Relationships across Borders," 77. Translocalism among Guinean refugees stressed the importance of child fostering as a livelihood strategy for women.

35 Robtel Neajai Pailey, "A Diaspora Returns: Liberian Then and Now," Seabreeze Journal (2008).

36 Ibid.

37 I transcribed direct quotes from the president's speech at the Liberian Studies Association Annual Meeting in Monrovia, Liberia, 13 May 2009.

38 Elizabeth Holzer, "A Case Study of Political Failure in a Refugee Camp," Journal of Refugee Studies 25, no. 2 (2012): 257-81; "18 Years Is Enough: Kufour Says 'No Justification' for Liberians in Ghana," News Service Reports, 26 March 2008.

39 James Butty, "Liberia's President Fires Officials Who Left Amid Ebola Outbreak," Voice of America News, 27 August 2014, http://www.voanews.com/content/liberian-president-sacks-some-ministers-who-left-amid-ebola-outbreak/2429368.html. Commuters raised even greater tension during the 2014 Ebola outbreak when many refused to return to Liberia out of fear of contracting the deadly disease. President Johnson-Sirleaf responded by firing numerous Cabinet members.

40 Naohiko Omata, "The End of the Liberian Crisis? SubRegional Integration of Residual Refugees in West Africa" (paper presented at the annual meeting of the International Association for the Study of Forced Migration, Kolkata, India, 6-9 January 2013).

41 Van Hear, "From 'Durable Solutions"; Micah Trapp, "Remittances as Informal Aid: Livelihoods and Migration in a Liberian Refugee Camp," UNHCR New Issues in Refugee Research, research paper no. 266, 2013.

42 Gina Porter, K. Hampshire, P. Kyei, M. Adjaloo, G. Rapoo, and K. Kilpatrick, "Linkages between Livelihood Opportunities and Refugee-Host Relations: Learning from the Experiences of Liberian Camp-Based Refugees in Ghana," Journal of Refugee Studies 21, no. 2 (2008): 230-52.

43 Liberians were able to lease land for ninety-nine years; however, I encountered only two Liberian refugees who had been able to do so.

44 Bernadette Ludwig, "Wiping the Refugee Dust from My Feet': Advantages and Burdens of Refugee Status and the Refugee Label," International Migration (2013), doi: 10.1111/ imig.12111.

45 Tete, "Any place could be home," 113.

46 Sanders, "Everyday Entanglement." 